\title{
The Role of Human Capital Management Practices in Inculcating Learning Orientation and Its Relationship with Performance: A Systematic Literature Review
}

\author{
${ }^{1}$ Neenu Wilson and ${ }^{2}$ Sebastian Rupert Mampilly \\ ${ }^{I}$ Research Scholar, School of Management Studies, Cochin University of Science and Technology Kerala, India \\ ${ }^{2}$ Professor, School of Management Studies, Cochin University of Science and Technology Kerala, India
}

\section{Key focus of the study}

The concept of "human capital" has recently received attention from many researchers. They hypothesise that it represents the human factor in the organisation, the combined intelligence, skills and expertise that gives the organisation its distinctive character. Human capital management is an integrated effort to manage and develop human capabilities to achieve significantly high level of performance. Human Capital Management Practices (HCMP), are set of practices that are focused on organisational needs to provide specific competencies.

The present study aims, firstly, to explore the literature and describe human capital management practices (HCMP) in organisations. Secondly, it aims to examine the links between HCMP and employee performance. Thirdly, it aims to explore the mediating role of learning orientation in establishing the link between HCMP and performance of employees.

\section{Background to the study}

The highly competitive market scenario has made companies to mark a competitive advantage in their conduct. The only inimitable competitive edge is company's human capital. Armstrong (2006) defines human capital as all human abilities whether innate or acquired attributes, whose value could be augmented by appropriate development investments. As the 'war of excellence' escalates, it becomes important to explore the factors that influence employees' performance so that organisations can accomplish their top position in the global market.

Handling performance issues is one of the most common and challenging task a manager can face. Hit, Hokinson, Harrison and Summers (1994) described that for US firm to attain competitive advantage, they have to focus on the development and retention of human capital with a culture of creativity and life-long learning.

\section{Trends from the research literature}

The beginning of the resource-based view of the firm (RBV) is commenced by the work of (Penrose, 1959), later articulated by Rumlet (1984), Barney (1991) and Dierickx \& Cool (1989). According to the RBV, competitive advantage is dependent on the valuable, rare, and hard-to-imitate resources that reside within an organisation i.e. human capital. So it is apparent that management of the human capital pool (the collection of employee capabilities) through HR processes is now become the strategic aims of the organisation (Stiles \& Kulvisaechana). If the types and levels of skills are not equally distributed, such that some firms can obtain the talent they require and others cannot, then that form of human capital can be a basis of sustained competitive advantage.

Recently, an equally important strand emerged known as 'the knowledge-based view of the firm', which emphasises the requirement of the organisations to develop and augment the knowledge and learning capabilities of the employees through knowledge acquisition, knowledge sharing and transfer, to achieve competitive advantage (Grant, 1996).

Based on a study of learning orientation and market orientation, Mavondo, Chimhanzi, \& Stewart (2005) suggest that HR practices and Innovation are important mechanisms for transmitting the benefit of Learning Orientation and Market Orientation into performance outcomes.

\section{Research objectives}

The study had the objectives that follow:

- $\quad$ To explore the literature and describe human capital management practices (HCMP) in organisations.

- $\quad$ To examine the links between HCMP and employee performance.

- To explore the mediating role of learning orientation in establishing the link between HCMP and performance of employees. 


\section{Potential value of the study}

HCM practices, as an integrated multidimensional construct, have expanded the existing theory about learning orientation, which organisations need to boost the performance of its talents in this 21 st century. Organisations can benefit from human capital management practices because it leverages the most valuable asset - people - to improve business performance and help competitive advantage (Bontis \& Fitz-enz, 2002). It intends to show how organisations can benefit from HCMP because HCMP can lead employees to orient more towards learning. Furthermore, this HCMP could play a role in enhancing the performance and could influence employees' intentions to remain with their organisations.

\section{Research approach}

\section{Research design}

The researchers conducted a systematic review of the literature. According to Tranfield, Denyer, \& Smart (2003), a systematic review identifies the key scientific contributions relevant to a subject by using extensive literature searches of published and unpublished studies. By using transparent and reproducible procedures, systematic reviews improve the quality and outcomes of review processes. Review processes generally consist of three parts: data collection, data analysis and synthesis. In this study, the authors conducted a critical analysis of the work of seminal authors in order to explore the literature and describe human capital management practices (HCMP) in organisations, to examine the links between HCMP and employee performance and to explore the mediating role of learning orientation in establishing the link between HCMP and performance of employees.

\section{Location of the data}

\section{Research method}

In this study, the systematic approach entailed extensive searches of relevant management databases. These were EBSCOhost, JSTOR, ProQuest, SAGE, Emerald and InterScience. The authors used these databases because they contain comprehensive data from accredited international and national multidisciplinary journals that specialise in human resource management, social, personnel and applied psychology as well as general management and organisational behaviour - the disciplines within which this research study resides. The authors conducted manual searches as well as Internet searches to identify secondary references and other publications of the researchers the authors identified in their original searches.

\section{Search terms and selected criteria}

In order to explore and describe the objectives of the study, the authors used the key words human capital management, learning orientation and performance in their literature search. They limited their search to English language publications between 1961 and 2013 that dealt specifically with above keywords. They chose 1961 as the starting date because the first scientific article that they could find referred to the above concepts appeared in that year. The original search identified more than 70 scientific papers, unpublished conference papers and reviews of the literature. However, the authors chose only published scholarly journals and examined human capital management in an organisational context. This resulted in 15 articles.

\section{Analysis and presentation of the data}

The authors used thematic analysis for analysing and reporting. This, according to Tranfield, Denyer, \& Smart (2003), is what one knows already and focuses on the extent to which there is consensus across various themes.

The authors evaluated the articles in terms of:

- the purposes of the studies

- whether they were qualitative or quantitative

- their methods of collecting data

- their key findings.

The authors categorised common themes that emerged from the data to achieve the three objectives of the study: in order to explore the literature and describe human capital management practices (HCMP) in organisations, to examine the links between HCMP and employee performance and to explore the mediating role of learning orientation in establishing the link between HCMP and performance of employees. 


\section{Results \\ Study objective 1: To explore the literature and describe human capital management practices (HCMP) in organisations}

The essence of human capital is the sheer intelligence of the organizational members (Bontis, 1998). According to Chen, Zhu and Xie (2004) human capital is an organization's combined human capacity which can find the best solutions for business problems from the knowledge of its individuals. It refers to such factors as employees "knowledge, skill, capacity, and attitudes in relation to fostering performances which customers are willing to pay for and the company's profit comes from. Brooking (1997) indicates that an organization's human asset contains skills, expertises, problem-solving abilities and leading strategies. High staff turnover can be an indication of losing human capital in an organization. Human capital can make organizations be highly dependent upon employees' knowledge and expertise to have more income, development, efficiency and profitability (Westphalen, 1999).

Competition has become an imperative strategy in today's global market. To develop a competitive advantage, it is crucial that companies truly leverage the workforce as a competitive weapon. Organisations are now in a focus of developing strategies for radically progressing workforce efficiency. Comprehensive development programmes are necessary to optimise companies' workforce not only to achieve business goals, but also, subsist and succeed for years to come. To achieve this mission, companies will need to invest resources to guarantee that employees have the information, skills, and competencies they need to work effectively in a rapidly changing and complex environment. This includes Human capital management practices as a part of their development activities so as to enhance the employee satisfaction and performance. Simply providing training and development programmes will not result in improved performance and higher productivity. Organisations need to look into the needs of the employees and ensure that Human Capital development policies are aligned with both company and individual goals (Wan, 2007).

Bassi \& McMurrer (2007), developed a system for assessing HCM, predicting organizational performance, and guiding organizations' investments in people. The empirical research conducted by them has revealed a core set of HCM drivers that predict performance across a broad array of organizations and operations. These drivers fall into five major categories: leadership practices, employee engagement, knowledge accessibility, workforce optimization, and organizational learning capacity. These drivers are explained as:

- Leadership /Managerial effectiveness: The effectiveness of managers' and leaders' ability to optimize the organization's human capital through communication, performance, feedback, efforts to instil confidence, and demonstration of key organizational values.

- Workforce optimization: The organisation's success in optimizing the performance of its workforce by means of developing and sustain talent (skills, competencies, abilities, etc.) and guiding and managing its application on the job.

- Learning capacity: The organisation's overall ability to learn, change and continually improve.

- Knowledge optimization: The extent of organisation's "collaborativeness" and current efforts and ability to share knowledge and ideas across the organisation.

- Talent retention: The organisation's ability to retain, engage and optimize the value of its talent.

Organizations' strengths and weaknesses in human capital management (HCM) can be assessed by monitoring the performance of each of $23 \mathrm{HCM}$ practices that fall within five broad HCM driver categories. In general, improvements or declines in organizational performance can be tied directly to improvements or declines in HCM practices (Bassi \& McMurrer, 2007).

\section{Study objective 2: To examine the links between HCMP and employee performance}

The link between human capital and performance is based on two theoretical aspects. First, the resource-based view of the firm and the second is the expectancy theory of motivation. The resource based view of the firm ascertain the significance of building a valuable set of resources and bundle them together in a unique and dynamic way for the success of an organisation (Stiles \& Kulvisaechana). Human capital is the most valuable resource of an organisation, in a real sense it is an 'invisible asset' (Itami, 1987).

Next is the expectancy theory of motivation, proposed by Victor Vroom. According to Holdford \& Lovelace-Elmore (2001), Vroom asserts, "intensity of work effort depends on the perception that an individual's effort will result in a desired outcome". Vroom suggests that "for a person to be motivated, effort, performance and motivation must be linked". According to Vroom, expectancy, instrumentality, and preferences are the three factors direct the intensity of effort put forth by an individual. In order to improve the effort-performance relationship, managers may engage in training to improve their capabilities and belief that, added effort will lead to better performance (Montana \& Charnov, 2008).

The world has been experiencing a 'war for talent', it is important to retain the existing talent and also to enhance their skills and abilities so as to improve the performance. According to a survey conducted by Hay Group in 2002 among the employees who worked in 330 companies in 50 countries, one third of them reported 
that they intended to resign from their jobs within the next two years. Many of the world's most admired companies acknowledge that they will lose half their senior executives in the next five years. This situation will be even worse in the coming years; organisations should manage their human capital pool more pertinently so that they can handle the unpredictable employee turnover. HCMP like employee engagement, leadership practices, learning capacity etc can have impact on employee retention and performance enhancement.

In their study, Nadoushan, Saeedi, Amidzadeh, \& Hosseini (2013), investigates the relationship between human capital management practices and employees' performace and they found a positive and meaningful relation between human capital and its dimension with employee perfromance. In their study they measured human capital using the indices like employees' creativity,employees' competence and employees' attitude. Human capital can be defined as a combination of employee's competence, attitude and creativity (Chen, Zhu, \& Xie, 2004).

According to Chen, Zhu, \& Xie (2004), human capital refers to factors as employees' knowledge, skill, capability, and attitudes in relation to fostering performances which customers are willing to pay for and the company's profit comes from. Wan (2007) asserts that human capital development policies can enhance employee satisfaction and it is evident from many research studies that employee satisfaction has positive significant relation with employee performance. According to Peccei (2004), satisfied employees are more willing to work hard and put in extra effort on behalf of the organisation, thus actively contributing to the overall productivity and effectiveness of the system.

Employee work performance is multidimensional and significant for organizational success (Dyne, Jehn, \& Commings, 2002) and effectiveness (Ohly \& Fritz, 2010). Work performance is described as "synonymous with behaviour it is what people do that can be observed and measured in terms of each individual's experience or level of contribution" (Pulakos, Arad, Donovan, \& Plamondon, 2000). George and Jones (2008) further indicated that performance can be viewed as an evaluation of the results of a person's behaviour which includes determining how well or poorly a task has been completed.

Performance provides a comprehensive picture of subordinate workplace behaviour (Kacmar, Collins, Harris, \& Judge, 2009), therefore several researchers have carried out studies on job performance behaviours with regard to supervisor rated task performance (Andrews, Kacmar, \& Harris, 2009), organizational citizenship behaviour (Andrews, Kacmar, \& Harris, 2009; Borman \& Motowidlo, 1997; Kacmar, Collins, Harris, \& Judge, 2009), and contextual performance (Borman \& Motowidlo, 1997). Kohli, Shervani, \& Challagalla (1998), have hypothesized that sales personnel having high learning orientations are expected to use self-regulation strategies, which help in developing skills and knowledge, and thereby improving performance.

\section{Study objective 3: To explore the mediating role of learning orientation in establishing the link between HCMP and performance of employees.}

Learning Orientation has been found to have mediating effects in research literature. Results of large and diverse literature analysis shows that employees' learning orientation is positively related to their performance, satisfaction, and commitment and HCMP are related to employees' satisfaction and commitment. The study's major hypothesis that employees' learning orientation mediates the relationship between HCMP and their performance was also supported. The empirical research carried out by Bassi and McMurrer (2007) identified five major drivers for Human capital management practices that can predict organisational performance and steer the investment decisions of organisation in people. These are leadership practices, employee engagement, knowledge accessibility, workforce optimization, and organizational learning capacity.

The significance of research in learning is fuelled by recognition that learning might be "the next source of competitive advantage" or "the only source of competitive advantage" (Dickson, 1992). Similarly, Lukas (1996) examined that "organisational learning is believed by many researchers as a key to future organisational success". Burgeoning concepts like organisational learning, learning organisation and learning orientation are not only semantic, but different in its substance. A learning organisation defined by, Pedler, Boydell, \& Burgoyne (1989) as one "that facilitates the learning of all its members and continually transforms itself". On the other hand, organisational learning refers to the expansion of new knowledge or insights that have the capability to stimulate the behaviour (Easterby-Smith, 1997). Thus, a learning orientation is the manifestation of the organisation's tendency to learn and adapt consequently (Mavondo, Chimhanzi, \& Stewart, 2005). As a result learning orientation is a wider concept that espouses many aspects of adaptation and change. This distinction is important because, some organisations can invest considerably in, for example, training, it may not be able to adapt and change itself with the varying advancements.

Baker and Sinkula (1999) demonstrated the mediating effect of LO in their study. He proposes that a firm's learning orientation is likely to indirectly affect organizational performance by improving the quality of its market-oriented behaviours and directly influence organizational performance by facilitating the type of generative learning that leads to innovations in products, procedures, and systems. Also he asserts that higher order learning processes may be critical in creating a sustainable competitive advantage in the firm. Many 
researchers have found evidence for a relationship between innovativeness and performance (Damanpour, Szabat, \& Evan, 1989; Hurly \& Hult, 1998; Narver \& Slater, 1990; Sinkula, Baker, \& Noordewie, 1997). Researchers have frequently mentioned learning orientation as one of the antecedents of innovativeness (Calantone, Cavusgil, \& Yushan, 2002; Wang, 2008).

Kohli, Shervani, \& Challagalla (1998), have hypothesized that sales personnel having high learning orientations are expected to use self-regulation strategies, which help in developing skills and knowledge, and thereby improving performance. Many researchers have found evidence for a relationship between innovativeness and performance (Damanpour, Szabat, \& Evan, 1989; Hurly \& Hult, 1998; Narver \& Slater, 1990; Sinkula, Baker, \& Noordewie, 1997). Researchers have frequently mentioned learning orientation as one of the antecedents of innovativeness (Calantone, Cavusgil, \& Yushan, 2002; Wang, 2008). Innovation is an important consequent of HCMP. Innovation sometimes requires the vision to predict what the market may become. That is, a firm with a strong learning orientation may recognize that customer satisfaction may not always be maximized through a strict interpretation of the feedback received from current customers, channels, and competitors but instead through innovative disruptions to the status quo that consider, but do not rely solely on outside-in processes (Baker \& Sinkula, 1999).

\section{Conceptual Framework}

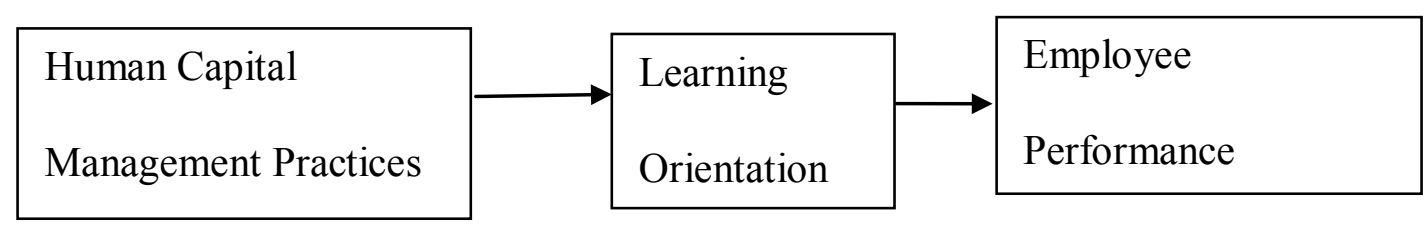

\section{Discussion}

Here, the authors elaborate on the achievement of the three study objectives and the implications of HCMP for human resource practitioners and managers.

\section{Study objective 1}

The authors have achieved their first study objective: 'to explore the literature and describe human capital management practices (HCMP) in organisations.'

Human capital which called human resources capital (Shun Wang, 2011) is backbone of intangible assets and is considered as a vital element in organizations' value (Royal \& O'Donnell, 2008). It includes all intellectual assets of organizations like employees' knowledge and expertise (which enable them to solve organizational problems and meet customers' needs and desires (Ditillo, 1998). This kind of capital is remembered as the most important criterion of intellectual capital (Cornachione, 2010) illustrates organizations' ability to find the best solution by focusing employees' knowledge (Bontis, 1998). Human capital shows knowledge inventory of employees (Bontis \& Fitz-enz, 2002) and is a vital resource of strategic innovation (Bontis, 1998). Human capital is one of the most important and in deeds the most important intellectual asset in organizations, because these assets are creativity resources. The capital includes employees knowledge in an organizations contain competencies, skills and abilities (Bontis, Keow, \& Richardson, 2000). The organizations are not owners of these capitals and employees exiting of organizations face them with new treatments (Bontis, 1998).

The authors finally achieved their first study objective by incorporating the important models of HCM that distinguishes the antecedents from the consequences of HCM.

\section{Study objective 2}

The authors achieved their second study objective, which was 'to examine the links between HCMP and employee performance.

Background to this study reveals that, it is a challenge to the organisation to keep pace with the changing competitive structure of the global market and also to uphold their employees to the expected level of performance. It is clear from the literature that it is a challenge for organisations to develop and enhance the performance of their most talented and skilled staff. Therefore, the managers in organisations are responsible for creating work environments that engage and retain employees. If organisations can develop and foster a learning orientation amongst employees by addressing the factors in the framework, they could become better workplaces where sustainable performance and retaining talent is not a problem but a competitive differentiator. Organisations can benefit from HCMP because it will enhance the employee's positive attitudes like satisfaction, commitment, innovation and there by augmenting the performance of employees and thus towards the organisational success and effectiveness. It can help organisations to retain talent and influence the intentions of skilled employees to remain with their organisations. Therefore, it is clear that HCMP, which is a 
multidimensional construct, could help organisations to retain the talents of skilled employees and hence their performance.

\section{Study objective 3}

The authors also achieved their third study objective, which was 'to explore the mediating role of learning orientation in establishing the link between HCMP and performance of employees'.

Learning orientation influences the propensity of the firm to create and use all kinds of knowledge, not just market-based knowledge. More important, it influences the degree to which firms are likely to promote generative learning as a core competency (Sinkula, Baker, \& Noordewie, 1997). Firms with strong learning orientations encourage, or even require, employees to constantly question the organizational norms that guide their MIP activities and organizational actions (Day, 1977; Garvin, 1993; Sinkula, Baker, \& Noordewie, 1997). In this respect, learning orientation affects the degree to which organizational members are encouraged, even required, to "think outside the box." Hence, it has a direct bearing on the degree to which higher order learning occurs (Slater \& John, 1994).

Managers who show a high learning orientation and high leadership development intentions also have a higher intention to stay in their organization. In fact organizations develop human capital for their own interest of have a highly capable workforce, therefore presenting more interesting career paths. This is understood by managers as higher commitment from the organization which can be rewarded by the individuals with a higher loyalty. Therefore, our expectation is that the learning orientation and leadership development intentions, together with organizational commitment, positively influence talent retention.

A learning orientation is likely to increase the rate of internal and external change in a company, but the process of establishing a learning orientation takes time. Changes in a firm's learning orientation, as Garvin (1993) notes, are "the product of carefully cultivated attitudes, commitments, and management processes that have accrued slowly and steadily over time". It is the combination of a strong market orientation and a strong learning orientation that is likely to lead to the type of learning that has been cited as the true source of sustained competitive advantage (Dickson, 1992).

Employees can get human capital through their competence, attitude and intellectual agility (Roos, Dragonetti, Edvinsson, \& Roos, 1997). Black and Lynch (1996) found that 10\% increase in the level of staffs' education can enhance efficiency about $9 \%$ in productive firms, and $13 \%$ in non-productive firms. Moreover, improving the level of employees ${ }^{\text {ee }}$ knowledge can increase their creativity, efficiency, and the customerse profitability, satisfactory and loyalty (Bontis, 2001). The staffs who apply their knowledge in the firm can provide competitive edge, and as a result, the organizations promote their salary. Teamwork can develop organizational performance through enhancing their innovativeness and creativity to present applicable ideas and learning capacity at work. For instance, teamwork is one of the important mechanisms for collective learning and knowledge exchange among team members.

\section{Conclusion}

This study determined that organisations can benefit from human capital management practices because it leverages the most valuable asset - people - to improve business performance and help competitive advantage. It can orient the employees more towards learning and thus augment performance of the employees. Also, 'HCM Practices' represents a comprehensive multidimensional construct. It is distinct from other HRM practices and seems capable of enabling organisations to enhance the performance of employees. Also, learning orientation (LO) has an impact on acquiring knowledge and its subsequent application for performing tasks. The pivotal role that HCMP plays is obvious. Human resource practitioners and managers must understand that they cannot always enhance performance using tangible means. Traditional strategies, like benefits, incentives and development opportunities, will become ineffective. The intangible phenomenon like learning orientation is also important and often ignored.

\section{Limitations of the study}

The construct of HCMP, like most social constructs, is complex. This might pose a limitation to the framework if it has omitted some variables. The researchers have done their best to be objective in developing the framework of HCMP and in considering the construct's relation to learning orientation and employee performance. Nevertheless, some subjectivity is a possibility.

\section{Suggestions for future research}

The authors have made theoretical recommendations to increase HCMP in organisations. They have not ruled out the possibility of building onto the framework as a topic for future research because there could be other variables that apply in different contexts. The current environment calls for the development of a survey instrument that organisations can use to understand whether, and how, employees interpret their HCMP of their 
organisations and to help organisations to enhance the learning orientation and performance of the employees. Furthermore, a study into the links between HCMP and learning orientation in different generations could also be useful for enhancing performance and could reveal possible differentiating factors.

\section{References}

[1]. Andrews, M. C., Kacmar, K. M., \& Harris, K. J. (2009). Got political skill? The impact of justice on the importance of political skill for job performance. Journal of Applied Psychology , 94, 1427-1437.

[2]. Baker, W. E., \& Sinkula, J. M. (1999). The Synergistic Effect of Market Orientation and Learning Orientation on Organizational Performance. Journal of the Academy of Marketing Science, 411-412.

[3]. Balck, S. E., \& L, M. L. (1996). Human Capital Investment and Productivity. The American Economic Review , 86, $263-267$.

[4]. Barney, J. B. (1991). Firm resources and sustained competitive advantage. Journal of Management, 17, 99-120.

[5]. Bassi, L., \& McMurrer, D. (2007, March). Maximizing Your Return on People. Harvard Business Review , 1-10.

[6]. Blundel, R., Dearden, L., Meghir, C., \& Sianesi, B. (1999). Human Capital Investment: The Returns from Education and Training to the Individual, the Firm and the Economy. Institute for fiscal studies, 1-23.

[7]. Bontis, N. (2001). Assessing knowledge assets:A Review of the Models Used to Measure Intellectual Capital. International Journal of Management Reviews , 3 (1), 41-60.

[8]. Bontis, N. (1998). Intellectual capital: an exploratory study that develops measures and models. Management Decision , 63-76.

[9]. Bontis, N., \& Fitz-enz, J. (2002). Intellectual capital ROI: A causal map of human capital antecedents and consequents. Journal of Intellectual Capital , 3, 223-247.

[10]. Bontis, N., Keow, W. C., \& Richardson, S. (2000). Intellectual capital and business performance in Malaysian industries. Journal of Intellectual Capital , 1 (1), 85-100.

[11]. Borman, W. C., \& Motowidlo, S. J. (1997). Task performance and contaxtual performance: the meaning for personnel selection research. Human Performance, 10(2), 99-109. , 99-109.

[12]. Brooking, A. (1997). Management of intellectual capital. Long Range Planning, 30 (3), 364-365.

[13]. Calantone, R. J., Cavusgil, S. T., \& Yushan, Z. (2002). Learning orientation, firm innovationcapability, and firm performance. Industrial Marketing Management , 31 (6), 515-524.

[14]. Chen, J., Zhu, Z., \& Xie, H. Y. (2004). Measuring intellectual capital:a new model and empirical study. Journal of Intellectual Capital , 5 (1), 195-212.

[15]. Cornachione, E. B. (2010). Investing in Human Capital: Integrating Intellectual Capital Architecture and Utility Theory. The Journal of Human Resource and Adult Learning , 6 (1).

[16]. D'Amato, A., \& Herzfeldt, R. (2008). Learning orientation,organizational commitment and talent retention across generations:A study of European managers. Journal of Managerial Psychology , 929-953.

[17]. Damanpour, F., Szabat, K. A., \& Evan, W. M. (1989). The relationship between types of innovation and organizational performace. Journal of Management Studies , 26 (6), 587-601.

[18]. Day, G. S. (1977). Diagnosing the Product Portfolio. Journal of Marketing, 29-38.

[19]. Dickson, P. (1992). Toward a general theory of competitive rationality. Journal of Marketing, 56, 69-83.

[20]. Dierickx, I., \& Cool, K. (1989). Asset stock accumulation and sustainability of competitive advantage. Management Science , 35, 1504-1511.

[21]. Ditillo, A. (1998). Intellectual Capital - Navigating in the New Business Landscape. Business Process Management Journal , 4 (1), 85-88.

[22]. Dyne, L. V., Jehn, K. A., \& Commings, A. (2002). Differential impacts of strains on two forms of work: Individual employee sales and creativity. Journal of Organizational Behavior, 23, 57-74.

[23]. Easterby-Smith, M. (1997). Disciplines of organisational learning: contributions and critiques. Human Relations , 50 (9), 10851113 .

[24]. Farrell, M. A. (1999). Antecedents and Consequences of A Learning Orientation. Marketing Bulletin , 38-51.

[25]. Garvin, D. A. (1993). Building a Learning Organization. Harvard Business Review, 78-91.

[26]. Grant, R. M. (1996). Toward a knowledge-based theory of the firm. Strategic Management, 17, 109-122.

[27]. Hitt, M. A., Hoskisson, R. E., Harrison, J. S., \& Summers, T. P. (1994). Human capital and strategic competitiveness in the 1990s. Journal of Management Development , 13 (1), 35-36.

[28]. Holdford, D., \& Lovelace-Elmore, B. (2001). Applying the Principles of Human Motivation to Pharmaceutical Education. Journal of Pharmacy Teaching, 8 (4), 1-18.

[29]. Hurly, R. F., \& Hult, G. T. (1998). Innovation, market orientation and organizational learning:an integration and empirical examination. Journal of Marketing, 62 (3), 42-54.

[30]. Ingraham, P. W., Selden, S. C., \& Moynihan, D. P. (2000). People and Performance: Challenges for the Future Public Service-the Report from the Wye River Conference. Public Administration Review , 60 (1).

[31]. Itami, H. (1987). Mobilising invisible assets. Boston: HBS Press .

[32]. Jha, S., \& Bhattacharyya, S. S. (2013). Learning Orientation and Performance Orientation: Scale Development and Its Relationship with Performance. Global Business Review , 43-54.

[33]. Jones, G. R., \& George, J. M. (2008). Essentials of Contemporary Management . McGraw-Hill Companies.

[34]. Kacmar, K. M., Collins, B. J., Harris, K. J., \& Judge, T. A. (2009). Core self-evaluations and job performance: The role of the perceived work environment. Journal of Applied Psychology , 94 (6), 1572-1580.

[35]. Kohli, A. K., Shervani, T. A., \& Challagalla, G. N. (1998). Learning and Performance Orientation of Salespeople: The Role of Supervisors. Journal of Marketing Research , 35 (2), 263-274.

[36]. Lukas, B. A. (1996). Striving for quality: the key role of internal and external customers. Journal of Market Focused Management , $1(2), 175-187$.

[37]. M, S. J., E, B. W., \& T, N. (1997). A framework for market-based organizational learning: Linking values, knowledge, and behaviour. Journal of the Academy of Marketing Science , 25 (4), 305-318.

[38]. Mavondo, F. T., Chimhanzi, J., \& Stewart, J. (2005). Learning orientation and market orientation:Relationship with innovation, human resource practices and performance. European Journal of Marketing, 39 (11/12), 1235-1263.

[39]. Montana, P. J., \& Charnov, B. H. (2008). Management (4 ed.). United States of America: Barron's Educational Series, Inc.

[40]. Nadoushan, M. E., Saeedi, N., Amidzadeh, M., \& Hosseini, A. A. (2013). The relationship between human capital management and employees' performance. Elixir International Journal , 13471-13475. 
[41]. Narver, J. C., \& Slater, S. F. (1990). The Effect of a Market Orientation on BusinessProfitability. Journal of Marketing , 54 (4), 2036.

[42]. Nybakk, E. (2012). Learning orientation, innovativeness and financial performance in traditional manufacturing firms: a higherorder structural equation model. International Journal of Innovation Management, 16 (5), 28pp.

[43]. Nzuve, S. N., \& Bundi, E. G. (2012, September). HUMAN CAPITAL MANAGEMENT PRACTICES AND FIRMS PERFORMANCE: A SURVEY OF COMMERCIAL BANKS IN. Retrieved January 6, 2014, from http://www.ssrn.com/: http://papers.ssrn.com/sol3/papers.cfm?abstract_id=2144691

[44]. Ohly, S., \& Fritz, C. (2010). Work characteristics, challenge appraisal, creativity, and proactive behavior: A multi-level study. Journal of Organizational Behavior , 31, 543-565.

[45]. Peccei, R. (2004). Human Resource Management and the Search for the Happy Workplace. Rotterdam: Erasmus University Rotterdam.

[46]. Pedler, M., Boydell, T., \& Burgoyne, J. G. (1989). Towards the learning company. Management Education and Development , 20 (1), 1-8.

[47]. Penrose, E. T. (1959). The theory of the growth of the firm. New York: Wiley.

[48]. Pulakos, E. D., Arad, S., Donovan, M. A., \& Plamondon, K. E. (2000). Adaptability in the workplace: Development of a taxonomy of adaptive performance. Journal of Applied Psychology , 85 (4), 612-624.

[49]. Razi, N., \& More, E. (2012). Human Capital and Performance Management in High Performing Service Industry: A Case of the Impact of an Acquisition. Journal of Accounting - Business \& Management, 19 (2), 15-43.

[50]. Roos, G., Dragonetti, N. C., Edvinsson, L., \& Roos, J. (1997). Intellectual Capital: Navigating in the New Business Landscape. Basingtoke: Macmillan Publishers Limited.

[51]. Royal, C., \& O’Donnell, L. (2008). Differentiation in Financial Markets: The Human Capital Approach. Journal of Intellectual Capital , 9 (4), 668-683.

[52]. Rumlet, R. (1984). Towards a strategic theory of the firm. Competitive Strategic Management, 556-570.

[53]. Schultz, T. W. (1961). Investment in human capital. American Economic Review , 51, 1-17.

[54]. Seleim, A., Ashour, A., \& Bontis, N. (2007). Human capital and organizational performance: a study of Egyptian software companies. Management Decision , 45 (4), 789-801.

[55]. Shun Wang, M. (2011). Intellectual Capital and Firm Performance. Annual Conference on Innovations in Business \& Management. London.

[56]. Sinkula, J. M., Baker, W. E., \& Noordewie, T. (1997). A framework for market-basedorganizational learning: linking values, knowledge, and behaviour. Journal of the Academy of Marketing Science, 25 (4), 305-318.

[57]. Slater, S. F., \& John, C. N. (1994). Does Competitive Environment Moderate the Market Orientation-Performance Relationship? Journal of Marketing , 58 (1), 46-55.

[58]. Stiles, P., \& Kulvisaechana, S. (n.d.). Human capital and performance:A literature review. Retrieved February 5, 2014, from http://www.bus.tu.ac.th/usr/sab/articles_pdf/research_papers/dti_paper_web.pdf

[59]. Tranfield, D., Denyer, D., \& Smart, P. (2003). Towards a methodology for developing evidence-informed management knowledge by means of systematic review. Retrieved from http://dx.doi.org/10.1111/1467-8551.00375.

[60]. Wan, H. L. (2007). Human capital development policies: enhancing employees' satisfaction. Journal of European Industrial Training, 31 (4), 297-322.

[61]. Wang, C. L. (2008). Entrepreneurial Orientation, Learning Orientation, and Firm Performance. Entrepreneurship Theory and Practice, 32 (4), 635-657.

[62]. Westphalen, S. (1999). Measuring Reporting Intellectual Capital: Experiences, Issues, and Prospects. OECD. Amsterdam. 